\title{
EFFECTS OF PROPOLIS EXTRACT SUPPLEMENTATION ON GROWTH PERFORMANCE, BODY COMPOSITION, FEED UTILIZATION AND HEAMATOLOGICAL PARAMETERS OF NILE TILAPIA, OREOCHROMIS NILOTICUS JUVENILE
}

\author{
A.M.A. El-Hais ${ }^{1}$ and Ebtehal E. Hussein ${ }^{2}$ \\ ${ }^{1}$ Department of Animal Production, Faculty of Agriculture, Tanta University, Egypt. \\ ${ }^{2}$ Department of Poultry Production, Faculty of Agriculture, University of Minoufia, Shebin El-Kom.
}

(Received 25/10/2016, Accepted 1/12/2016)

\section{SUMMARY}

$\mathrm{T}$ The present study was conducted to estimate the effects of propolis extract dietary supplementation on Nile tilapia Oreochromis niloticus juvenile performance, whole body composition, hematological, biochemical and histological indices. Four experimental diets were formulated including the control as basal diet (D1) without any supplementation, followed by three diets supplemented with propolis extract at 3,6 and $12 \mathrm{~g} / \mathrm{kg}$ diet D2, D3 and D4, respectively. Fish $(3.78 \pm 0.03 \mathrm{~g})$ were randomly divided into twelve $(80 \mathrm{~L})$ aquaria in triplicates $(15$ fish per replication). The obtained results showed that, fish fed diets supplemented with propolis extract at levels of 3 and $6 \mathrm{~g} \mathrm{~kg}^{-1}$ had the highest values of final body weight, weight gain percentage, specific growth rate, whole body protein and ash. Moreover, fish fed propolis supplemented diet recorded higher feed intake than the control diet. However, there were no significant differences $(P>0.05)$ in feed efficiency ratio, FER, protein efficiency ratio, PER and survival rate, SR $(\%)$ of fish fed different levels of propolis extract and control diet. Blood biochemical parameters appeared no hazard effects of dietary propolis on kidney and liver function. Heamatological indices referred to an increase $(\mathrm{p}<0.05)$ in red blood cell counts and hemoglobin especially with D3 diet. Generally, no hazard histological changes were observed with propolis extract for intestine and liver sections. It may be concluded that, propolis dietary supplementation at 3 and $6 \mathrm{~g} \mathrm{~kg}^{-1}$ diet could be improve Nile tilapia juvenile's growth, body composition and hematological parameters

Keywords: Propolis, Nile tilapia, growth, carcass, hematological parameters

\section{INTRODUCTION}

The fish products have high nutritional value components containing protein and lipids which are useful for human health (Yousefian et al., 2011). So, there were serious attempts to develop fish production and enhance the quality of fish products without hazard effects on human feeding.

Many efforts have ben performed to use the natural products from the animal or plant origin as feed additives in different types as anti-microbial and anti-oxidants to enhance efficiency of feed utilization and animal productive performance. It can be believed that certain natural food ingredients would be better and safer than synthetic ones because a lot of these compounds, such as plant phenolics, may be used as an antioxidant and antimicrobial substrate. In addition, many protection methods such as using antioxidant molecules were developed to reduce environment damage by pesticides damage to environment by pesticides.

Propolis (bee glue) is a substance of plant and animal origin and sticky dark-colored material that honeybees collect from different living plants mix modified in the hive through addition of salivary secretions and mix with wax to use it in the building and adaptation of their nests, mainly to fill out cracks in the bee hive (Pinheiro-Filho, 1998). Also, propolis color varies from green, red to dark brown. It has been used in folk medicine so it has attracted researchers' interest because of its several biological and pharmacological properties.

Chen et al. (2007) showed that, propolis is a mixture contains about 50-70\% resins and 10\% essential oils, coming from plant origin, mixed with 30-50\% wax for proper consistency and 5-10\% pollen, gained from being transported in the bees' pollen baskets. A chemical analysis of propolis samples declared that, 


\section{El-Hais and Hussein}

presence of bioflavonoids, some vitamins as B1, B2, B6, C, E, and minerals as manganese, iron, calcium, aluminum and vanadium. Furthermore, it is explained that propolis had an effect on the cytoplasmic membrane and can inhibit enzyme activity as well as bacterial motility (Mirzoeva et al., 1997 and Koru et al., 2007).

In fish, many experiments were performed and stated that propolis can be valid as a growth promoter (Meurer et al., 2009), immunitostimulant (Talas, and Gulhan, 2009) and hepato-protective agent (Deng et al., 2011). So, propolis may be useful for tilapias which are found as freshwater in Africa and many tropical, subtropical and temperate regions of the world (El-Sayed, 2004). Also, tilapia are widely reared for many reasons contained excellent candidates for aquaculture, fast growth rates, resistance of different environmental conditions and disease, good reproduction in capture, a fast growth range and the high ability to utilize natural and artificial diets. Furthermore, it is a preferable to purify propolis by extraction with solvents because this process may help to remove the inert material and preserve the polyphenolic fractions. For example, extraction with ethanol is the most commonly used solvent and may be suitable to get de-waxed propolis extracts rich in polyphenolic fractions (Popova et al., 2004).

The present study was determine the effect of dietary supplementation with propolis extract on growth performance, body composition, growth performance, body composition, and hematological parameters of Nile tilapia, Oreochromis niloticus juvenile.

\section{MATERIALS AND METHODS}

\section{Propolis extract}

Propolis extract was prepared following the method described by Cuesta et al. (2005). Crude propolis sample was collected from bee units at Gharbia governorate bee farm. Extraction was done by using absolute ether rate of $10 \mathrm{ml}$ per g crude propolis in air-sealed bottles which were continuously shaken in darkness for $24 \mathrm{hrs}$ at ordinary room temperature. After that the extract was filtered twice, dried under vacuum and finally stored in pervious bottles at $4{ }^{\circ} \mathrm{C}$ until performing the study. The extractions were added to the diet during the cooling stage of formulation process to avoid the heating effect.

\section{The experimental diets}

Four experimental diets were formulated including the control as basal diet (D1) without any supplementation, followed by three diets supplemented with propolis extract at 3,6 and $12 \mathrm{~g} / \mathrm{kg}$ diet D2, D3 and D4, respectively (Table 1). The basal diet was formulated to contain about (30\%) crude protein

Table (1): Feed ingredient (g $100 \mathrm{~g}-1)$ and proximate chemical analysis (\%) of the basal diet.

\begin{tabular}{lc}
\hline Item & Basal diet \\
\hline Ingredients g $/ 100 \mathrm{~g}$ & \\
\hline Fish meal $(72 \%)$ & 10 \\
Soybean meal $(44 \%)$ & 40 \\
Yellow corn & 15 \\
Wheat bran & 18 \\
Wheat flour & 14 \\
Soybean oil & 2 \\
Vitamin & 0.5 \\
Minerals & 0.5 \\
Total & 100 \\
Chemical composition $(\%$ DM) & \\
Dry Matter & 89.96 \\
Crude protein & 30.75 \\
Ether extract & 5.05 \\
Crude fiber & 5.71 \\
Crude ash & 5.6 \\
NFE & 52.89 \\
Calculated energy value GE $\left(\text { Kcal kg }^{-1}\right)^{2}$ & 439.01 \\
\hline I NFE Nitrogen free extract was calculated by the difference: (100 - (protein + lipid + ash + Crude fiber).
\end{tabular}


2, $2 G E$ (Gross Energy): gross energy calculated as 5.64, 9.44 and 4.11 Kcal per gram of protein, lipid and carbohydrate, respectively after (NRC, 1993).

and $(426.3832 \mathrm{Kcal} / \mathrm{kg} \mathrm{DM})$ gross energy. All ingredients were first ground to a small particle size (approximately $250 \mathrm{~mm}$ ). Dry ingredients were thoroughly mixed prior to adding water to 35-40 \% moisture. Diets ingredient were passed through a mincer $35 \mathrm{~mm}$ diameter like spaghetti strands, air dried and stored in airtight containers at $5^{\circ} \mathrm{C}$ until fed or analyzed for chemical composition.

\section{Fish, facility and feeding trial}

Nile tilapia, Oreochromis niloticus fingerlings were obtained from a local fish hatchery (Saft Khaled, Al-Bahira Governorate).

Fish were acclimated to the experimental condition for 7 days in fiber glass tank $1000 \mathrm{~L}$ before starting the experiment; during which they fed a commercial diet. After that, fish $(3.78 \pm 0.03 \mathrm{~g})$ were distributed at a rate of 15 fish per 80-L glass aquarium. Fish in each aquarium were fed one of the tested diets twice a day; six days a week at a rate of $3 \%$ of their body weight for 84 days. A half of aquarium's water was siphoned daily with fish feces and replaced by dechlorinated tap water. Every two weeks, fish per each aquarium were group-weighed by a digital scale (accurate to $\pm 0.001 \mathrm{~g}$ ) and feed quantity was adjusted accordingly. Dead fish once appeared in any aquarium were recorded and removed. At the start of the experiment, $50 \mathrm{~g}$ fish sample were collected and immediately frozen $\left(-20^{\circ} \mathrm{C}\right)$ and reserved for initial proximate body chemical analysis. At the end of the experiment, fish were collected from each aquarium, counted, and weighed. Then, five fish were taken from each aquarium for the proximate chemical analysis.

\section{Water quality parameters}

Water temperature and dissolved oxygen were measured daily using an oxygen meter (YSI Model 58, YSI Industries, and Yellow Spring Instruments, OH, USA). The pH-value was monitored twice weekly using an electronic $\mathrm{pH}$ meter (pH pen, Fisher Scientific, Cincinnati, OH, USA). Total ammonia, nitrite, and nitrate were measured weekly using spectrophotometer (Spectronic 601, Milton Roy Company, San Diego, CA, USA) according to APHA, (1998).Total alkalinity was monitored twice weekly using the titration method of Golterman et al., (1978).

During the 84 days feeding trial, the mean values of water quality parameter $( \pm \mathrm{SD})$ were: water temperature $26.3 \pm 0.5^{\circ} \mathrm{C}$; dissolved oxygen $6.3 \pm 0.4 \mathrm{mg} / \mathrm{L} ; \mathrm{pH} 8.1 \pm 0.1$; total ammonia $0.18 \pm 0.09 \mathrm{mg} / \mathrm{L}$; nitrite $0.06 \pm 0.02 \mathrm{mg} / \mathrm{L}$; nitrate $0.08 \pm 0.05 \mathrm{mg} / \mathrm{L}$, and total alkalinity $182 \pm 33 \mathrm{mg} / \mathrm{L}$ as $\mathrm{CaCO}_{3}$. All water quality parameters herein are within the acceptable range for rearing Nile tilapia according to Boyd, (1984).

\section{Fish performance and feed utilization}

Fish growth performance and feed utilization parameters were calculated according to Cho and Kaushik (1985) as follow:

Average weight gain $(\mathrm{AWG}, \mathrm{g} /$ fish $)=[$ final body weight $(\mathrm{g})$ - initial body weight $(\mathrm{g})]$; Average daily gain, $(\mathrm{ADG}, \mathrm{g} / \mathrm{fish} /$ day $)=[\mathrm{AWG}(\mathrm{g}) /$ Experimental period (days) $]$; (day);

Specific growth rate $(\mathrm{SGR}, \% \mathrm{~g} /$ day $)=100$ [Ln final weight $-\mathrm{Ln}$ initial weight] / Experimental period

Feed conversion ratio $(\mathrm{FCR})=$ feed intake $(\mathrm{g}) /$ body weight gain $(\mathrm{g})$;

Protein efficiency ratio $(\mathrm{PER})=$ gain in weight $(\mathrm{g}) /$ protein intake in feed $(\mathrm{g})$;

Survival rate $(\mathrm{SR} \%)=($ total number of fish survived/total number of fish stocked $) \times 100$

\section{Proximate chemical analyses}

Samples of the experimental diets and fish were chemically analyzed to determine dry matter (DM), crude protein, and ether extract (EE), crude fiber $(\mathrm{CF})$, and ash contents according to the methods of AOAC (2000).

Nitrogen free extract (NFE) was calculated by differences, by deducting the sum of percentages of moisture, CP, EE, CF and ash from 100. Gross energy (GE) contents of the experimental diets and fish samples were calculated by using factors of 5.64, 9.44 and $4.12 \mathrm{kcal} / \mathrm{g}$ of protein, lipid and carbohydrates, respectively (NRC, 1993). 


\section{Blood collection and hematological analysis}

At the end of the experiment, fish ( $\mathrm{n}=5$ of each treatment) were randomly taken and an anesthetized using $3 \mathrm{ml}$ pure clove oil (dissolved in $10 \mathrm{~mL}$ absolute ethanol) as an anesthetic material. For the hematological parameters analysis, blood samples, (5-mL of whole blood at each collection), were collected from the caudal peduncle of fish in plastic heparinized vials for determination of hemoglobin concentration $(\mathrm{Hb})$ using commercial colorimetric kits (Diamond Diagnostic, Egypt), packed cell volume (PCV\%) and Red blood cell ( RBC) according to Stoskopf , (1993).

\section{Serum collection and biochemical analysis}

Other blood samples were collected in dried plastic tubes and centrifuged at $3500 \mathrm{rpm}$ for $15 \mathrm{~min}$ to obtain the blood serum for determination of total protein (Gornall et al., 1949), aspartate aminotransferase (AST) and alanine aminotransferase (ALT) (Varley et al., 1976) using a spectrophotometer (model 5010, Germany).

\section{Histological analysis}

Three fish were randomly selected from each aquarium $(n=9$ per treatment). The head and tail of each fish were cut off and the viscera were dissected and preserved in $10 \%$ neutral buffered formalin (Thermo Fisher, Kalamazoo, MI) for $48 \mathrm{~h}$. The following day, the viscera were washed with water several times and preserved in $75 \%$ ethyl alcohol for further processing. The liver and intestine were separately dissected and examined. Tissues were routinely dehydrated in ethanol, equilibrated in xylene, and embedded in paraffin according to standard histological techniques. All tissues were longitudinally sectioned then sections were cut to $5 \mu \mathrm{m}$ increments, mounted on glass slides and stained routinely with hematoxylin and eosin (Hand E) stain. Finally, the sections were immersed after staining in xylene and set in a Permount medium for examination through the light electric microscope.

\section{Statistical analysis}

The analyzed data were expressed as means \pm SEM, standard error. Differences among dietary treatments were tested by one-way ANOVA using Statistical Analysis System (SAS) version 8.02 for Windows. Differences were considered significant at the $P<0.05$ followed by Duncan (1955).

\section{RESULTS AND DISCUSSION}

\section{Growth parameters, nutrient utilization and survival rates}

Growth performances and nutrient utilization of Nile tilapia fed test diets for 84 days are shown in Table (2). The growth performance and feed intake (FI) of fish groups fed the diets containing propolis extract improved compared with fish fed control diet. Fish fed diets $\mathrm{D}_{2}$ and $\mathrm{D}_{3}$ significantly $(P \geq 0.05)$ showed the highest final body weight $(\mathrm{FBW})$, weight gain $(\mathrm{WG}, \mathrm{g} /$ fish ) and specific growth rate (SGR $\%$ /day). Also, there were no significant $(P \leq 0.05)$ between $\mathrm{D}_{3}$ and $\mathrm{D}_{4}$ diets. Moreover, fish fed propolis supplemented diet recorded higher FI than the control group. However, there were no significant differences $(P \leq 0.05)$ in protein efficiency ratio, PER and survival rate $(\%)$, SR of fish fed different levels of propolis extract and control diet ,D1.

Table (2): Effect of dietary supplementation with propolis on growth performance, nutrient utilization and survival rate.

\begin{tabular}{lllll}
\hline \multirow{2}{*}{ Parameter* } & \multicolumn{3}{c}{ Experimental diets (g Propolis/ kg diet) } \\
\cline { 2 - 5 } & \multicolumn{1}{c}{$\mathrm{D} 1$} & \multicolumn{1}{c}{$\mathrm{D} 2$} & $\mathrm{D} 3$ & $\mathrm{D} 4$ \\
\hline Initial body weight (g/fish) & $3.80 \pm 0.02$ & $3.76 \pm 0.01$ & $3.80 \pm 0.04$ & $3.75 \pm 0.01$ \\
Final body weight (g/fish) & $16.20^{\mathrm{c}} \pm 0.63$ & $20.66^{\mathrm{a}} \pm 0.54$ & $19.86^{\mathrm{ab}} \pm 0.57$ & $18.33^{\mathrm{b}} \pm 0.80$ \\
Body weight gain(g/fish) & $12.40^{\mathrm{c}} \pm 0.48$ & $16.9^{\mathrm{a}} \pm 0.28$ & $16.06^{\mathrm{ab}} \pm 0.85$ & $14.58^{\mathrm{b}} \pm 0.80$ \\
Specific growth rate $\left(\%\right.$, day $\left.^{-1}\right)$ & $1.73^{\mathrm{c}} \pm 0.05$ & $2.03^{\mathrm{a}} \pm 0.05$ & $1.97^{\mathrm{ab}} \pm 0.03$ & $1.89^{\mathrm{b}} \pm 0.07$ \\
Feed intake & $16.12^{\mathrm{b}} \pm 0.34$ & $18.02^{\mathrm{a}} \pm 0.39$ & $18.23^{\mathrm{a}} \pm 0.25$ & $17.58^{\mathrm{a}} \pm 0.30$ \\
Feed conversion ratio & $1.30 \pm 0.09$ & $1.07 \pm 0.01$ & $1.14 \pm 0.06$ & $1.21 \pm 0.04$ \\
Protein efficiency ratio & $2.50 \pm 0.29$ & $3.05 \pm 0.05$ & $2.86 \pm 0.20$ & $2.70 \pm 0.12$ \\
Survival rate $(\%)$ & $93.33 \pm 2.89$ & $95.56 \pm 1.67$ & $97.78 \pm 1.01$ & $95.56 \pm 1.67$ \\
\hline *Means in the same row within each item having different superscript are significantly different $(P<0.05)$.
\end{tabular}


The pervious experiments with Nile tilapia (Oreochromis niloticus) fingerlings pointed that supplementation of brown propolis extract at 1.83-2.74 g/ kg (Meurer et al., 2009) and ethanolic extract of propolis at $10 \mathrm{~g} / \mathrm{kg}$ or crude propolis (Abdel- Rhman, 2009) significantly improved the growth indices. These studies suggest that, preferable effects of propolis on fish growth performance may be due to the propolis extract compounds and its antimicrobial, biological and antioxidant activities which resulting in improving digestion and absorption of digestive system. In contrast, few studies (Velotto et al., 2010 and Kashkooli et al., 2011) explained that, propolis had no beneficial effect on fish weight gain and specific growth rate of rainbow trout (Oncorhynchus mykiss) although muscular development was increased. This confliction of results attributed to different doses of propolis and/or its origin especially, propolis analysis may be varied according to some factors such as the suitable exudates, fish species use different climate and other environmental conditions (Chen and Wong, 1996 and Nieva-Moreno et al., 1999). The mechanisms of propolis action have been widely estimated by different in vitro and in vivo methods (Sforcin, and Bankova, 2011).The mode of action of propolis extracts depends on some flavonoids and phenolic acids which comprising about $25-30 \%$, and has many biological and pharmacological properties including antimicrobial, anti-inflammatory, anti-allergic and vasodilator actions, immune-potentiation and antitumor effects (Prytzyk et al., 2003). Moreover, its phenolic components extend the capability of cells to prevent apoptosis contributing and reduce oxidative stress, due to its anti-inflammatory and antioxidative actions (Geckil et al., 2005).

\section{Whole body proximate analysis}

Fish showed some changes in the final whole body proximate compositions of Nile tilapia fed the test diets compared to those of the starting initial values (Table 3). Whole body protein and ash were significantly $(P<0.05)$ higher in fish fed diets $\mathrm{D}_{2}$ and $\mathrm{D}_{3}$ and the lowest values were in diet $\mathrm{D}_{1}$. Whole there were no significant differences $(P \leq 0.05)$ in moisture and lipids contents.

Table (3): Effect of dietary supplementation with propolis on carcass composition of Nile tilapia (Oreochromis niloticus).

\begin{tabular}{|c|c|c|c|c|c|}
\hline \multirow[b]{2}{*}{ Parameter ${ }^{*}$} & \multirow[b]{2}{*}{ At the start } & \multicolumn{4}{|c|}{ Experimental diets (g Propolis $/ \mathrm{kg}$ diet) ${ }^{* *}$} \\
\hline & & D1 & $\begin{array}{c}\mathrm{D} 2 \\
\text { At the end }\end{array}$ & D3 & D4 \\
\hline Moisture & $80.56 \pm 0.7$ & $68.69 \pm 0.08$ & $68.23 \pm 0.45$ & $68.26 \pm 0.63$ & $68.11 \pm 0.61$ \\
\hline Ash (\%) & $4.54 \pm 0.19$ & $4.84 \pm 0.08 \mathrm{~b}$ & $5.51 \pm 0.28 \mathrm{a}$ & $5.48 \pm 0.34 \mathrm{a}$ & $5.08 \pm 0.48 \mathrm{ab}$ \\
\hline Crude protein & $11.27 \pm 0.05$ & $15.15 \pm 0.34^{b}$ & $16.09 \pm 0.20^{\mathrm{a}}$ & $16.04 \pm 0.26^{\mathrm{a}}$ & $15.84 \pm 0.12^{\mathrm{ab}}$ \\
\hline Crude lipid & $3.04 \pm 0.13$ & $11.31 \pm 0.19$ & $11.28 \pm 0.17$ & $11.14 \pm 0.33$ & $11.29 \pm 0.16$ \\
\hline
\end{tabular}

Abdel-Hakim et al. (2014) found that, whole body DM, CP and ash percentages of mono-sex Nile tilapia (Oreochromis niloticus) fingerlings were significantly $(P<0.05)$ increased by propolis (Bee Glue) dietary treatment. Similarly, Deng et al. (2011) deducted that, propolis level supplementation of $0.5 \%$ increased whole-body protein and lipid content of juvenile eel, Anguilla japonica. Also, Wafaa et al. (2014) obtained a higher tilapia fish DM content by diet supplemented with black cumin seed while the whole body $\mathrm{CP}$ content was significantly $(\mathrm{P}<0.05)$ enhanced by green tea, black seed and propolis extract groups. So, the present higher values of whole protein of fish groups supplemented with propolis supplementation may be returned that flavonoids compounds in propolis improve nutrient metabolism, feed ingestion and absorption.

\section{Blood biochemical parameters}

Data of Table (4) clearly indicated significant $(P<0.05)$ gradual decrease of blood glucose, BUN and ALT parameters as the level of propolis was increased. Moreover, blood parameters as creatinine, AST, albumin and TP showed non-significant differences between all the experimental treatments. These results are agreed with Deng et al. (2011) who found that, dietary supplementation of $1 \mathrm{~g} / \mathrm{kg}$ ethanolic extract of propolis with rainbow trout significantly decreased plasma AST and plasma triglycerides levels. Long-term administration of propolis (8 weeks) in juvenile rainbow diet especially, with9 $\mathrm{g} / \mathrm{kg}$ diet had no significant alterations in content of serum TP, albumin, globulin, LDL, HDL, TG and function of liver enzymes expressed as AST, ALT concentration (Kashkooli et al., 2011). Increasing glucose production in control group may be happening to meet the increasing demands for energy from fish under stress. So, dietary propolis was accompanied with recorded and desirable results of blood glucose level in this experiment. 
Table (4): Effect of dietary supplementation with propolis on Biochemical parameters of Nile tilapia (Oreochromis niloticus)..

\begin{tabular}{lcccc}
\hline \multirow{2}{*}{ Parameter $^{*}$} & \multicolumn{3}{c}{ Experimental diets (g Propolis/ kg diet) } \\
\cline { 2 - 4 } & $\mathrm{D} 1(0)$ & $\mathrm{D} 2$ & $\mathrm{D} 3$ & $\mathrm{D} 4$ \\
\hline Glucose $(\mathrm{mg} / \mathrm{dl})$ & $122.8 \pm 3.06^{\mathrm{a}}$ & $93.2 \pm 5.1^{\mathrm{b}}$ & $89.1 \pm 2.33^{\mathrm{b}}$ & $45.7 \pm 3.76^{\mathrm{c}}$ \\
$\mathrm{BUN}(\mathrm{mg} / \mathrm{dl})$ & $7.45 \pm 0.70^{\mathrm{a}}$ & $4.34 \pm 0.52^{\mathrm{b}}$ & $4.22 \pm 0.21^{\mathrm{b}}$ & $4.84 \pm 0.09^{\mathrm{b}}$ \\
Creatinine $(\mathrm{mg} / \mathrm{dl})$ & $0.25 \pm 0.02$ & $0.27 \pm 0.01$ & $0.22 \pm 0.03$ & $0.17 \pm 0.07$ \\
$\mathrm{AST}(\mu / \mathrm{ml})$ & $152 \pm 2.01$ & $149 \pm 1.23$ & $149 \pm 3.22$ & $151 \pm 1.98$ \\
$\mathrm{ALT}(\mu / \mathrm{ml})$ & $38 \pm 0.76^{\mathrm{a}}$ & $27 \pm 1.31^{\mathrm{b}}$ & $26 \pm 0.88^{\mathrm{b}}$ & $22 \pm 2.11^{\mathrm{b}}$ \\
$\mathrm{Albumin}(\mathrm{g} / \mathrm{dl})$ & $0.73 \pm 0.01$ & $0.74 \pm 0.02$ & $0.64 \pm 0.01$ & $0.896 \pm 0.01$ \\
$\mathrm{TP}(\mathrm{g} / \mathrm{dl})$ & $2.62 \pm 0.09$ & $2.65 \pm 0.10$ & $2.70 \pm 0.21$ & $2.61 \pm 0.11$ \\
$\mathrm{Alkaline}$ phosphatase $(\mathrm{IU} / \mathrm{L})$ & $22.37 \pm 1.87$ & $23.9 \pm 0.92$ & $24.63 \pm 2.04$ & $22.96 \pm 2.63$ \\
\hline Means in the same row within each item having different superscript are significantly different $(P<0.05)$. & \\
$*^{*}$ D , control diet without propolis supplementation, diets D2,D3, and D4, contained control diet plus $3.0 \%, 6 \%$ and \\
12\% propolis , respectively
\end{tabular}

\section{Hematological indices}

Hematological parameters of fish fed tested diets were presented in Table 5. Overall, dietary treatments had no significant effect $(P>0.05)$ on hematological indices except for red blood cells. The higher RBCs count $(P<0.05)$ was obtained by fish fed the diet supplemented with $6 \mathrm{~g} / \mathrm{kg}$ diet of propolis extract followed by 3 and $12 \mathrm{~g} / \mathrm{kg}$ diet while, control group recorded the lowest one.

Table (5): Effect of dietary supplementation with propolis on Hematological parameters of Nile tilapia (Oreochromis niloticus).

\begin{tabular}{lcccc}
\hline \multirow{2}{*}{ Parameter } & \multicolumn{4}{c}{ Experimental diets (g Propolis /kg diet)** } \\
\cline { 2 - 5 } & $\mathrm{D} 1$ & $\mathrm{D} 2$ & $\mathrm{D} 3$ & $\mathrm{D} 4$ \\
\hline $\mathrm{Hgb}$ & $9.43 \pm 1.2$ & $9.96 \pm 0.8$ & $10.16 \pm 0.6$ & $9.52 \pm 0.91$ \\
$\mathrm{RBC}$ & $2.02 \pm 1.1^{\mathrm{b}}$ & $3.87 \pm 0.3^{\mathrm{a}}$ & $3.90 \pm 0.43^{\mathrm{a}}$ & $2.28 \pm 0.9^{\mathrm{b}}$ \\
Total Leukocyte $\left(10^{6} / \mathrm{mm}^{3}\right)$ & $27.24 \pm 1.04$ & $27.20 \pm 2.21$ & $27.10 \pm 1.44$ & $27.13 \pm 1.62$ \\
Lymphocytes $(\mu \mathrm{l})$ & $24912 \pm 762$ & $25058 \pm 1969$ & $24892 \pm 1234$ & $25040 \pm 1302$ \\
Neutrophils $(\mu \mathrm{l})$ & $1918 \pm 120$ & $1836 \pm 134$ & $1782 \pm 109$ & $1608 \pm 201$ \\
Monocytes $(\mu \mathrm{l})$ & $411 \pm 163$ & $306 \pm 107$ & $433 \pm 98$ & $490 \pm 112$ \\
$\mathrm{PCV}(\%)$ & $36.83 \pm 3.07$ & $37.72 \pm 4.20$ & $36.53 \pm 1.89$ & $35.96 \pm 1.11$ \\
$\mathrm{MCV}(\mathrm{fl})$ & $98 \pm 6.20$ & $99.60 \pm 5.64$ & $100.58 \pm 2.01$ & $99.72 \pm 3.81$ \\
$\mathrm{MCH}(\mathrm{pg})$ & $38.08 \pm 8.52$ & $39.22 \pm 4.34$ & $40.77 \pm 3.00$ & $38.59 \pm 2.95$ \\
\hline${ }^{*}$ Means in the same row within each item having different superscript are significantly different $(P<0.05)$. \\
* D1, control diet without propolis supplementation , diets D2,D3, and D4, contained control diet plus $3.0 \%, 6 \%$ \\
and12\% propolis , respectively
\end{tabular}

These results agree with Dotta et al. (2015) who demonstrated that, dietary mixtures of propolis and Aloe barbadensis extracts improved hematological parameters of Nile tilapia which due to a favored significant reduction in the number of gill parasites.

Propolis has several biological and pharmacological effects and its mechanisms of action have been widely studied in different animals. Kasai et al. (2011) indicated that, antioxidant activity of propolis includes the contribution against neuronal death.

\section{Histopathological indices}

Histological changes in the liver and intestines of the fish fed the extract of propolis for 12 weeks illustrated in Figs. (1 and 2). The liver exhibited a normal structure and there was no histopathological alteration, with hepatocytes presenting a homogenous cytoplasm, and a large central or sub central spherical nucleus (Fig. $1_{\mathrm{A}}$ ). The hepatic parenchyma of fish fed diet $\mathrm{D}_{2}$ showed no alterations but dilatation in the central vein (Fig. $1_{\mathrm{B}}$ ). Also, Focal hemorrhage was detected in the hepatic parenchyma associated with congestion in the hepatic sinusoids of fish fed diet $\mathrm{D}_{3}{ }^{+}$(Fig. $1_{\mathrm{C}}$ ). Additionally, congestion was detected in the central vein and sinusoids, hepatocytes contained larger deposits and the nuclei of the hepatocytes were pushed to the cell wall of fish fed diet $\mathrm{D}_{4}$ (Fig. $\left.1_{\mathrm{D}}\right)$. 

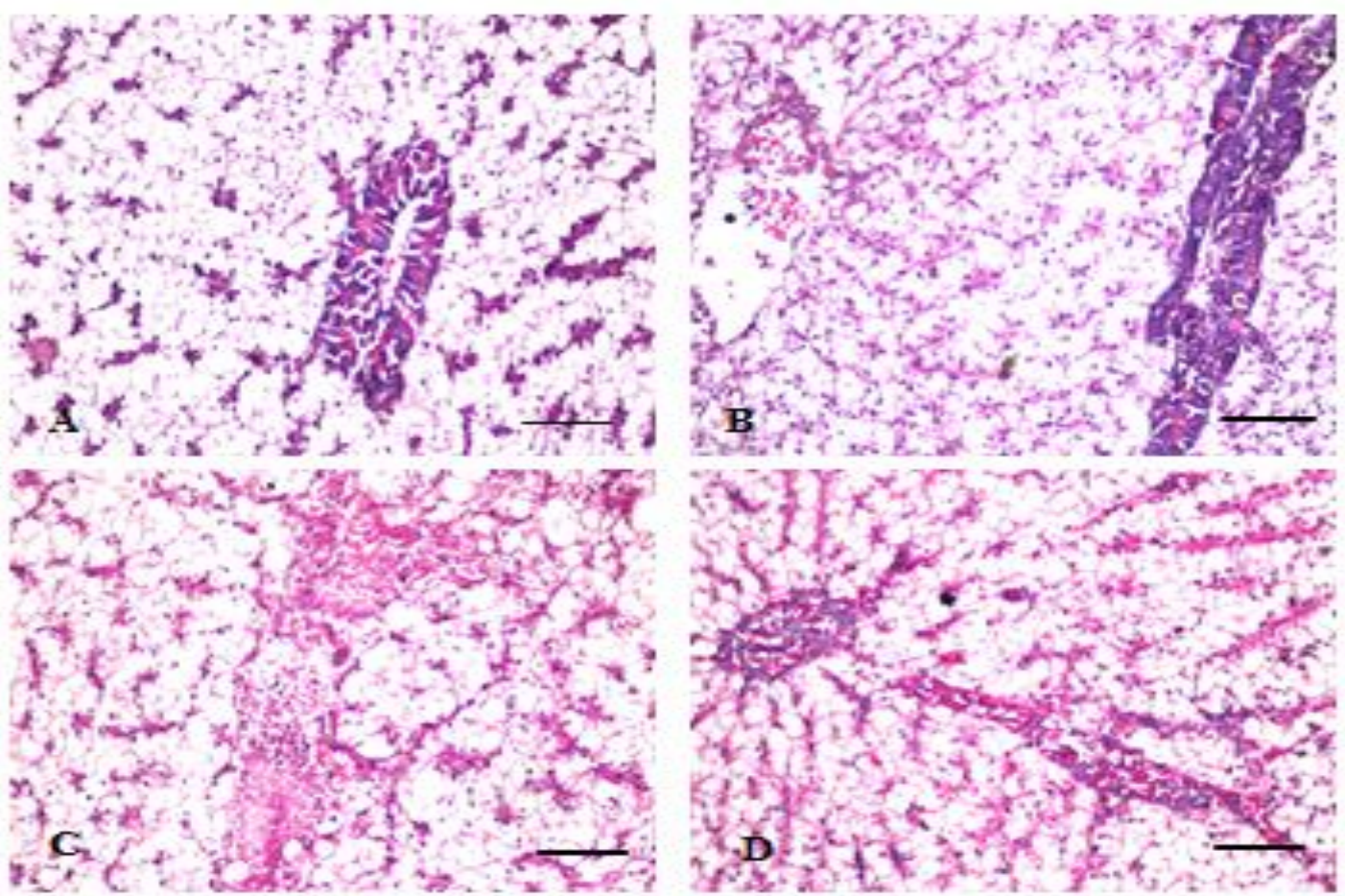

Fig. (1): Histopathological changes in liver of Nile tilapia fed control diet $\left(A, D_{1}\right)$, followed $\left(B, D_{2}\right)$ $, C, D_{3}$ and $D_{,} D_{4}$, respectively). (A) Showing normal histological structure. (B) Dilatation in the central vein in the liver structure of fish fed propolis at $\mathrm{D}_{2}$. Focal hemorrhage and congestion was detected in the hepatic sinusoids (C, D) of fish fed $\mathrm{D}_{3}$ and $\mathrm{D}_{4}$, respectively. (H\&E staining); scale bars $=40 \mu \mathrm{m}$.

No specific pathological changes were observed in the intestine of fish fed the control diet without any supplementation (Fig.2 A). However, the intestine of fish fed diets $\mathrm{D}_{2}, \mathrm{D}_{3}$ and $\mathrm{D}_{4}$ showed diffuse goblet cells formation in the lining mucosal epithelium associated with inflammatory cells infiltration in the underlying lamina propria (Fig. $2_{\mathrm{B}}, \mathrm{C}$ and ${ }_{\mathrm{D}}$ ). 

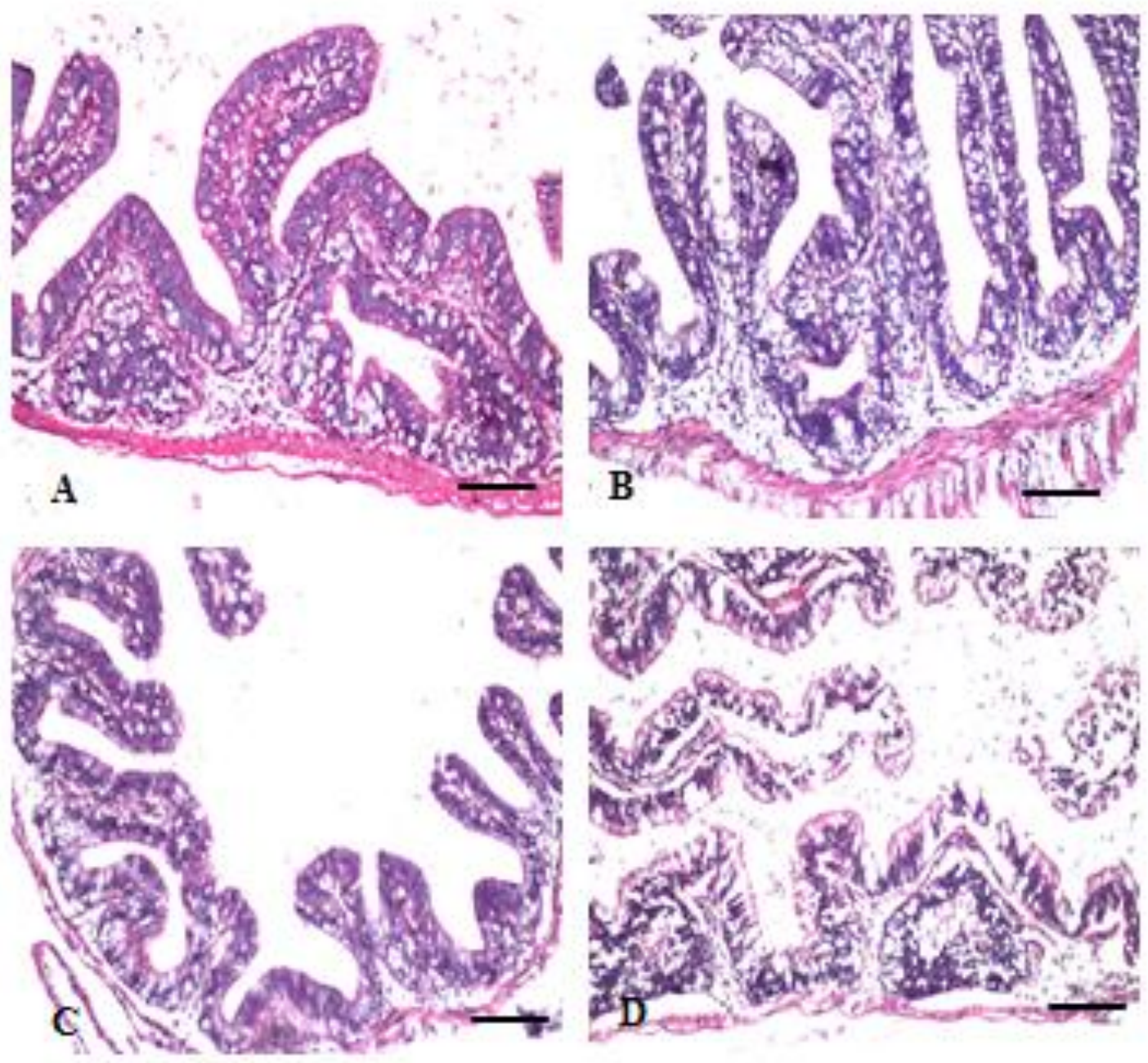

Figure (2): Intestine histology of Nile tilapia fed different diets (A, D1), followed $\left(B, D_{2}\right),\left(C, D_{3}\right)$ and $\left(D_{,}, D_{4}\right)$ with 3respectively). Fish fed diets supplemented with Propolis at different levels exhibit diffuse goblet cells formation was observed in the lining mucosal epithelium associated with inflammatory cells infiltration in the underlying lamina propria. ( $\mathrm{H}$ and $\mathrm{E}$ staining); scale bars $=\mathbf{4 0}$ $\mu \mathrm{m}$. diets $\left(\mathrm{A}, \mathrm{D}_{1}\right)$, followed $\left(\mathrm{B}, \mathrm{D}_{2}\right),\left(\mathrm{C}, \mathrm{D}_{3}\right)$ and $\left(\mathrm{D}, \mathrm{D}_{4}\right)$, respectively).

\section{CONCLUSION}

It may be concluded that, propolis dietary supplementation at 3 and $6 \mathrm{~g} / \mathrm{kg}$ diet could be improve Nile tilapia juvenile's growth, body composition, biochemical and hematological parameters

\section{REFERENCES}

Abdel-Hakim N.F., A.M. A-S Goda, M.E. Lashin, A.A. Al-Azab and H.M. Nazmi( 2014). The effect of using some natural growth promoters on growth performance and feed utilization of monosex Nile tilapia (Oreochromis niloticus), fingerlings. Egypt. J. Aquat. Biol. \& Fish, 18(3) : 67-78.

Abdel-Rhman, A.M.M. (2009). Antagonism of Aeromonas hydrophila by propolis and its effect on performance of Nile tilapia, Oreochromis niloticus. J. Fish \&Shellfish Immunology, 27: 454-459.

AOAC (1990). Official Methods of Analysis of the Association of Official Analytical Chemists, 15th Ed. Association of Official Analytical Chemists, Arlington, VA, USA.

Chen, P.C. and G. Wong (1996). Honey bee propolis: prospects in medicine. Bee World, 77: 8-15. 
Chen, C.R., Y.N. Lee, C.M.J. Chang, M.R. Lee and I.C. Wei (2007). Hot pressurized fluid extraction of flavonoids and phenolic acids from Brazilian propolis and their cytotoxic assay in vitro. Journal of the Chinese Institte of Chemical Engineers, 38: 191-196.

Cuesta, A., A. Rodríguez, M.Á. Estebanand, and J. Meseguer (2005). In vivo effects of propolis, a honeybee product, on gilthead seabream innate immune responses. Fish \& Shellfish Immunology, 18: $71-80$.

Dawood, M.A.O., S. Koshio, M. Ishikawa and S. Yokoyama (2015a). Effects of heat killed Lactobacillus plantarum (LP20) supplemental diets on growth performance, stress resistance and immune response of Red sea bream, Pagrus major. Aquaculture, 442: 29-36.

Dawood, M.A.O., S. Koshio, M. Ishikawa and S.Yokoyama (2015b). Interaction effects of dietary supplementation of heat-killed Lactobacillus plantarum and $\beta$-glucan on growth performance, digestibility and immune response of juvenile red sea bream, Pagrus major. Fish Shellfish Immunol., 45: 33-42.

Deng, J., Q. An, B. Bi, Q. Wang, L. Kong and X. Zhang, (2011). Effect of ethanolic extract of propolis Oreochromis niloticus (1.) against Aeromonas on growth performance and plasma biochemical hydrophila infection. Journal of the world parameters of rainbow trout (Oncorhynchus mykiss). Aquaculture society vol. 41, no. 2. Fish Physiol. Biochem., 37: 959-967.

Dotta, G., J.L.P. Mourino, A. Jatobá, R.E.B.Morán, C. Pilati, and M.L. Martins (2015). Effect of dietary supplementation with propolis and Aloe barbadensis extracts on hematological parameters and parasitism in Nile tilapia. Brazilian Journal of Veterinary Parasitology, 24(1): 66-71.

Doumas, B. T., W. A. Watson and H. C. Biggs (1971). Albumin standards and Management of serum albumin with bromocresol green. Chin. Chim. Acta., 31:87-96.

Duncan, M.B. (1955). Multiple ranges and multiple F-tests. Biometrics 11:1-42.

El-Sayed, A.-F.M. (2004). An overview of fish nutrition research in Egypt. Unpublished Report. Expert Consultation on Fish Nutrition Research and Feed Technology in Egypt. Abbassa, Abou Hammad, Sharkia, Egypt, 2 December 2004. Abbassa, World Fish Center. 14 pp.

Friedman, K. and D. S. Young (1997). Effects of disease on clinical laboratory tests, 3ed. AACC press.

Geckil, H., B. Ates, G. Durmaz, S. Erdogan, and I. Yilmaz (2005). Antioxidant, free radical scavenging and metal chelathing characeristics of propolis. American Journal of Biochemistry and Biotecnology, 1(1): 27-31.

Henry, R. J. (1964). Clinical Chemistry, Principles and Technics, 2 nd Edition, Harper and Row., P.525,1974.

Hesser, E. F. (1960). Methods for routine fish hematology. Progressive Fish Culturist, 22(4): 164-171.

Kasai, M., H. Fukumitsu, H. Soumiya, and S. Furukawa (2011). Ethanol extract of Chinese propolis facilitates functional re $\neg$ covery of locomotor activity after spinal cord injury. Evid.- Based Compl Alt, Article ID 749627, 9.

Kashkooli, O.B., E.E. Dorcheh, N. Mahboobi-Soofiani and A. Samie (2011). Long-term effects of propolis on serum biochemical parameters of rainbow trout (Oncorhynchus mykiss). Ecotox.Environ. Saf., 74: 315-318.

Koru, O., F. Toksoy., Y.M. Tunca, M. Baysallar, G.A. Uskudar, E. Akca, T. A. Ozkok, (2007). In vitro antimicrobial activity of propolis samples from different geographical origins against certain oral pathogens. Anaerobe, 13: 140-145.

Larsen, H. N. (1964). Comparison of various methods of hemoglobin detection of channel catfish blood. Prog. Fish-Cult., 26: 11-15.

Meurer, F., M.M. de Costa, D.A.D. de Barros, S.T.L. de Oliveira and O. P.S. da Paixa (2009). Brown propolis extract in feed as a growth promoter of Nile tilapia (Oreochromis niloticus, Linnaeus 1758) fingerlings. Aquac. Res., 40: 603-608.

Mirzoeva, O.K., R.N. Grishanin and P.C. Calder (1997). Antimicrobial action of propolis and some of its components: the effects on growth, membrane potential and motility of bacteria. Reseach in Microbiology, 152(3): 239-46. 


\section{El-Hais and Hussein}

Nieva-Moreno, M.I., M.I. Isla, N.G. Cudmani, M.A. Vattuone and A.R. Sampietro (1999). Screening of antibacterial activity of Amaicha del Valle (Tucuman, Argentina) propolis. J. Ethnopharmacol., 68: 97-102.

NRC (1993). Nutrition requirements of fish. National Research Council National academy press, Washington, D. C. 114 pp, USA.

Pinheiro-Filho, R. (1998). Criação de abelhas. Cuiabá: SEBRAE.

Popova, M., V. Bankova, D. Butovska, V. Petkov, B. Nikolova- Damyanova, A.G. Sabatini, G.L. Marcazzan and S. Bogdanov (2004). Validated methods for the quantification of biologically active constituents of poplar-type propolis. Phytochemical Analysis, 15: 235-240.

Prytzyk, E., A.P. Dantas, K. Salomão, A.S. Pereira, V.S. Bankova, , S.L. De Castro and F.R.A. Neto (2003). Flavonoids and trypanocidal activity of Bulgarian propolis. J. Ethnopharmacology, 88: 189193.

Sforcin, J.M. and V. Bankova ( 2011). Propolis: is there a potential for the development of new drugs?. J. Ethnopharmacol., 133: 253-260.

Talas, Z.S. and M.F. Gulhan (2009). Effects of various propolis concentrations on biochemical and hematological parameters of rainbow trout (Oncorhynchus mykiss). Ecotox. Environ. Safe. 72: 19941998.

Velotto, S., C.Vitale, E. Varricchio, and A. Crasto (2010). Effect of propolis on the fish muscular development and histomorphometrical characteristics. Acta. Vet. Brno., 79: 543-550.

Wafaa, E., I. Doaa, A. El-Murr and M. Rania (2014). Effects of Dietary Inclusion of Black Cumin Seeds, Green Tea and Propolis Extraction on Growth Parameters, Body Composition and Economic Efficiency of Nile Tilapia, Oreochromis niloticus. World Journal of Fish and Marine Sciences 6 (5): 447-452.

Young, D. S. and R. B. Friedman (2001). Effects of Disease on Clinical Laboratory Tests, 4th Edition, Vol. 1 and 2, Washington, DC, AACC Press.

Yousefian, M., M. Sharifrohani, H. Hosseinzadeh-Sahafi, F. Laloei, and C. Makhdoomi (2011). Heritability estimation for growth-related traits in juvenile wild common carp (Cyprinus carpio L.) in the south of Caspian Sea. Iranian Journal of Fisheries Sciences, 10(4): 740-748.

\section{تاثير اضافة مستخلص صمغ النحل على اداء النمو و تركيب الجسم وقياسات الدم والمؤشرات الهستولوجية

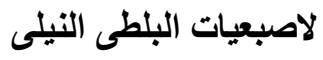

\footnotetext{
عبد العزيز عحم عبد العزيز الحايس 1 و ابتهال السيد حسين

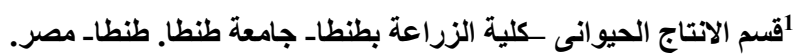

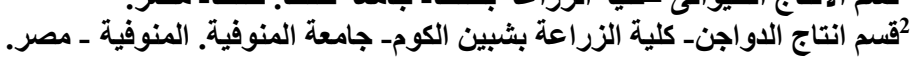

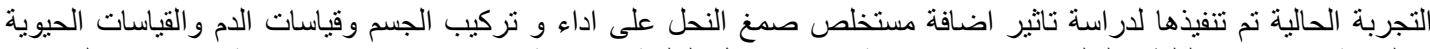

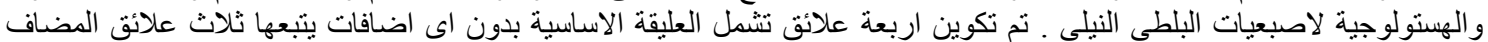

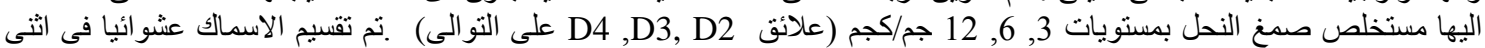

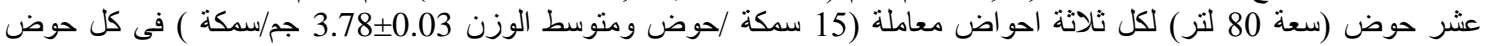

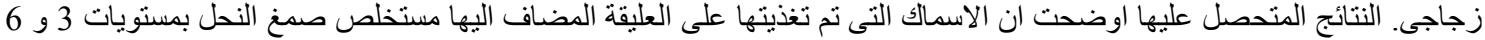

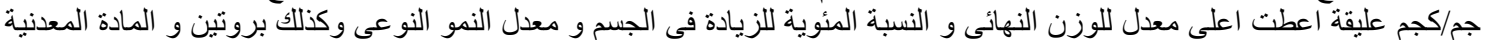

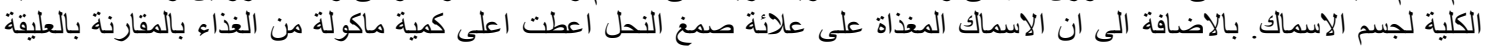

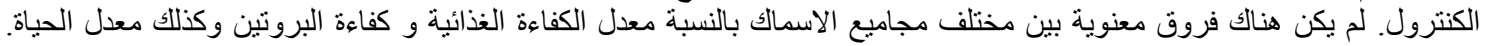

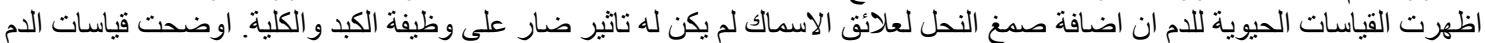

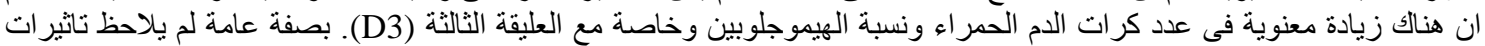

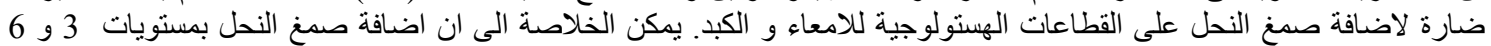

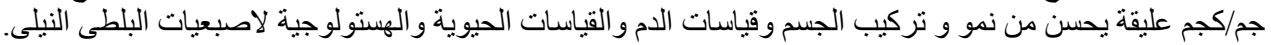

